\title{
MAPPING RECENT FLUCTUATIONS OF SHOESTRING GLACIER, MOUNT ST. HELENS \\ (Abstract)
}

\author{
by
}

\author{
Melinda M. Brugman
}

(California Institute of Technology, Pasadena, CA, U.S.A.)

\section{ABSTRACT}

The terminus position of Shoestring Glacier, Mount St. Helens, has pulsated over the last few centuries, generally following local climate trends, but the pattern of advance and retreat has been strongly modulated by effects of local volcanic activity. In this paper, I discuss the techniques employed to map and survey fluctuations in ice velocity, thickness, and terminus position of Shoestring Glacier. Solutions to major problems in acquiring and interpreting data peculiar to an active volcano are also explained Results show that this steep mountain glacier responds quickly and dramatically to local environmental changes. The effects of volcanic activity are distinguished from internal instabilities and local climate change by combining information obtained using a variety of techniques, including field surveying, contour-mapping using stereo-aerial photographs, photo-documentation, and published historical accounts. In this paper I will focus attention on surveying and mapping conducted since 1979 at Shoestring Glacier, but will also discuss methods used to identify historic and "prehistoric" glacier fluctuations back to the early 1800 s.

The field survey was conducted at the glacier from mid-1979 to late 1983, during several eruptive episodes, major earthquakes, and covering winter and summer velocity and thickness changes. (Brugman and Post, 1980; Brugman and Meier, 1981). Coordinates of glacier velocity markers and the survey reference net were monitored with several different theodolites and electronic distance meters. In addition, topographic maps of Shoestring Glacier and vicinity were made for the years between 1979 and 1982 , for the purpose of characterizing the drastic changes which occurred during the volcanic eruption of Mount St. Helens of May 18, 1980. The maps were constructed with $2 \mathrm{~m}$ contour intervals, using three sets of vertical aerial photographs. The difference between maps results in two plots showing the surficial changes caused by the volcanic field-checked against ground survey data on thickness change, using standard techniques. Overall, this study included monitoring glacier flow, configuration, and thickness changes at Shoestring Glacier since mid-1979, and also monitoring any changes in the local survey net due to ground deformation associated with nearby volcanic activity.

In addition, photographic and written documentation of recent glacier fluctuations at Mount St. Helens was compiled from a variety of sources, which included local explorers, scientists, mountaineers, aviators, and historians. From this information, I was able to obtain the general pattern of Shoestring Glacier terminus fluctuations since the early 1900 s.

To extend the study further back in time, I also mapped the local surficial geology surrounding Shoestring
Glacier using aerial photographs and ground studies. Because Mount St. Helens is a highly active, young volcano, a major problem was to distinguish glacier moraines, built during a recent ice advance, from volcanic levees built during passage of a recent lahar. Both lahar levees and glacier moraines exist along the glacier margin and most have been dissected and scoured by later mudflows. This study required the separate identification of glacial lag-till, from mudflow and rock avalanche debris. Comparison of depositional and erosional features generated by the several major lahars which decended over the Shoestring Glacier during the 1980 eruptions to pre-1980 surficial geology shows that glacier and lahar deposits are closely intermingled, but they can be distinguished on the basis of surface morphology obtained from aerial photographs, supported by field mapping of sedimentary structures. The dominant pre-1980 surficial deposits were laid down during a time of intense volcanism dating from 1800-1857, when the Shoestring Glacier was initially at its most advanced terminus position in its limited geologic record. During the early 1900s, several minor historic eruptions deposited ash and debris as distinctive englacial debris layers, which were well preserved within the glaciers on Mount St. Helens. Rock material deposited in the early to mid-1800s from glacier advances and volcanic eruptions can be distinguished from volcanic material deposited during the early $1900 \mathrm{~s}$ because of the minor effect these later eruptions had on the glaciers of Mount St. Helens.

This study shows that, over the last few centuries, repeated eruptions of Mount St. Helens have caused important changes in the mass balance of Shoestring Glacier. During several volcanic eruptions since 1800, the Shoestring and nearby glaciers have been deeply blanketed with rock ejecta and avalanche and mudflow debris, which could have increased the glacier mass balances. In contrast, the dominant effect of major volcanic eruptions on the Shoestring Glacier has led to strongly negative mass balances due to scouring, melting, and blasting away of glacier snow and ice. Deep incision of the glacier and its surrounding topography is clearly evident from the maps produced during this study, both during and before 1980. This melting and scouring occurred as pyroclastic flows and lahars swept down the glacier-filled canyon from the summit of the volcano and has probably occurred repeatedly since the canyon holding the Shoestring Glacier was first cut, approximately two thousand years ago. The eruption of Mount St. Helens on May 18, 1980, when the Shoestring Glacier was beheaded, deeply incised, and covered by volcanic ejecta and mudflow debris, is the most recent example of the highly variable environment in which the glacier continues to survive. 